COMPUTERS IN BUSINESS 
Also in the Macmillan Business Management and Administration series, edited by Alan Hale

PUBLISHED

David Brown and Michael J. Harrison: A Sociology of Industrialisation - an introduction

Terry Green and John Webster: Managing Mathematically

Peter Haine and Ernest Haidon: Computers in Business

Arthur Hindmarch, Miles Atchison and Richard Marke: Accounting - an introduction

Peter Ribeaux and Stephen Poppleton: Psychology and Work - an introduction 


\title{
Computers \\ in Business
}

\author{
Peter HAINE
}

Ernest HAIDON

M 
All rights reserved. No part of this publication may be reproduced or transmitted, in any form or by any means, without permission

First published 1978 by

THE MACMILLAN PRESS LTD

London and Basingstoke

Associated companies in Delhi Dublin

Hong Kong Johannesburg Lagos Meibourne

New York Singapore and Tokyo

\title{
British Library Cataloguing in Publication Data
}

\author{
Haine, Peter \\ Computers in business. - (Macmillan business \\ management and administration series). \\ 1. Business-Data processing \\ I. Title II. Haidon, Ernest \\ 651.8'4 HF5548.2
}

ISBN 978-0-333-19164-4 ISBN 978-1-349-15975-8 (eBook)

DOI 10.1007/978-1-349-15975-8

This book is sold subject to the standard conditions of the Net Book Agreement.

The paperback edition of this book is sold subject to the condition that it shall not, by way of trade or otherwise, be lent, resold, hired out, or otherwise circulated without the publisher's prior consent in any form of binding or cover other than that in which it is published and without a similar condition including this condition being imposed on the subsequent purchaser. 


\section{Editor's Introduction}

This series is a direct outcome of the opportunities and challenges created by the rapid expansion of higher and further education in the past decade.

The expansion involved changes in the structure of advanced education, through the CNAA, the Polytechnics, the Regional Management Centres and the professional bodies which encouraged staff to develop new and experimental teaching. Substantial changes have taken place in the definition, scope and methodologies of the social, administrative and management sciences leading to modifications in the presentation of these subjects. Many new fulltime students and staff have questioned traditional approaches and methods and have established more open ciscussion and debate on their courses. Demands for qualified manpower led to an expansion in part-time education and increased questioning by students in full-time jobs of the relevance of their studies.

Each of these developments has had a profound impact on the structure and content of courses and given fresh impetus to the discussion and modification of curricula and teaching methods in polytechnics, universities and colleges of further education. The editor and authors of the books in this series have made a deliberate attempt to respond to these changes.

The books set out to provide a comprehensive and up-to-date introduction to the ideas and methods of their subjects for specialist and non-specialist students in fields such as business arid management studies, social science and administration. Their aim is to help students who have little or no previous knowledge of them to achieve a mastery of the scope and basic techniques of their subjects and to use them critically and with imagination for further study or for practical professional applications. They also seek to make some contribution to discussions of teaching and learning problems in their field.

Many introductory books present their subjects as a coherent body of knowledge of which the logic is self-evident and the concepts and methods clear to the careful reader. Students do not always find this so. Confronted as they are by a well-established discipline which has developed a particular method that may not bear any obvious relationship to the way in which they have been accustomed to think or to realities as they see them, students often have difficulty in comprehending the significance and detail of the forms of analysis it employs. 
The editor and authors of the series felt that they should not take for granted the 'self-evident logic' of their subjects, but try to demonstrate to readers the ways in which their disciplines provide an effective framework for the analysis of problems in their field. When abstractions or concepts are introduced their functions and limitations are explained. Where methods or techniques are described the authors show why they take the form they do and the ways in which they may be used for particular tasks of analysis.

Students often criticise courses because their subjects or parts of them do not have any obvious, or immediate, practical applications. They may present what appear to be unnecessarily complicated ways of dealing with quite straightforward problems or, paradoxically, they may be regarded as oversimplifying or ignoring difficulties which are experienced in real situations. Criticisms of this sort are due to misunderstandings about the nature of subjects. Systems of knowledge provide generalisations which are derived from a variety of abstractions and models. Some of these yield tools of description and analysis that have direct applications. Others suggest ways of looking at problems that, however fruitful, may have only limited or indirect applications.

The authors have tried to make clear the relevance of their subjects. Where concepts and methods have direct applications they show how, and under what circumstances, they can usefully be applied. Where they are of indirect use they show how a process of simplification may isolate and draw attention to the important characteristics of a complex problem, or how the study of complicated or abstract aspects of a problem may throw fresh light on it.

The authors have rejected a view, relflected in many basic textbooks, that students at an introductory level should concentrate on 'learning up' the information and techniques of their subjects and not be troubled with discussions of concepts and analytical method. This 'descriptive' approach, which divorces the study of techniques from that of conceptual and analytical structures, makes it more rather than less difficult for students to appreciate how a technique has developed, why it takes a particular form and how it functions. As a result students can spend a considerable time trying to understand, with limited success, a method of describing and presenting information or a method of analysis and fail to achieve any real facility in using it. The discussion of concepts and analytical method also acquaints a student with some of the difficulties and controversies surrounding the ideas and techniques he is studying. Without such knowledge he is unlikely to appreciate their limitations or establish any real ability to discriminate between alternative approaches and methods.

One of the more important aims of education is to develop a student's capacity to formulate and solve theoretical and practical problems. It is clear that few business and administrative problems are in practice separable into the neat categories represented by disciplines such as economics, accounting, law, sociology, psychology and computing. But most courses are based on combinations of studies in these and similar discrete disciplines which are rarely effectively integrated. It is recognised that the development of bodies of knowledge which provide rigorous rather than superficial integrative approaches will be a long and difficult task. The editor and authors of the books in this series are aware of this problem and within their limitations have 
attempted to indicate points at which contributions from other disciplines are necessary to the analysis of the problems with which they are dealing. It is thus hoped that in the long run the series will make some contribution to the development of interdisciplinary approaches.

The problems outlined above are common in the teaching and learning of many subjects which, although emerging historically as systems for analysing and solving practical problems, have developed advanced methodologies and a logical order of presentation that may not bear an obvious relation to the practical problems with which they are supposed to be concerned.

Since the early 1950 s there has been a dramatic increase in the application of computer technology. There has been a parallel increase in the demand for courses on computer operations, systems analysis and data processing. The penetration of computerised processes into all spheres of business, administrative, scientific and technological activities has created as much pressure for the retraining of existing staff as for the recruitment of new personnel. Many who are not familiar with scientific or technological methods find it difficult to grasp the modes of analysis and technical concepts used in computing. And it is not easy to understand the advantages of these new methods over those which have been developed over years of practical experience. Thus, many students, confronted with the complexity of computer systems, rigorous analytical methods and a highly specialised technical vocabulary, have experienced difficulty, if not confusion, in attempting to grasp the subject. Rapid technical advance in the field with frequent new developments in methods and terminology have compounded students' problems. The authors of this text, who are experienced in the field, have sought to provide a clear exposition of the basic ideas and methods underlying their subject and to convey in simple and practical terms the analytical style and methods involved. Students who master the contents of their book should be in a position to understand the general nature of computing processes, undertake specific application tasks and appreciate new developments.

The editor and authors of the books in this series are conscious of their limitations in attempting to implement their ideas in writing and teaching and do not suppose that their presentation will solve students' learning problems. They do not ignore the critical importance of motivation and sustained and disciplined study as factors in effective learning. But they felt that if subjects were presented in a way that made their form and justification explicit rather than implicit this would aid teaching and learning.

In seeking to achieve their aims the books in the series have been subjected to a great deal of critical scrutiny. Each is written by more than one author. This has enabled authors to combine a comparison of views with a considerable, and sometimes uncomfortable, degree of mutual criticism. The editor and authors have all, in recent years, had considerable experience of designing and teaching new CNAA honours degree, diploma or professional courses. Their manuscripts have been discussed with colleagues in education and the professions and have been tested in classes with students.

My thanks as editor are owed to the authors who responded to my request to write the books in the form that I have outlined. This has involved them in an extremely demanding process. The fact that we shared 
some basic assumptions about education and learning was of great help. The editors and staff of Macmillan with whom we have worked have showed great patience and could not have done more in difficult circumstances to encourage the series. My thanks are also due to George Brosan, Maurice Peston and Bruce May, who through many discussions have significantly influenced my educational ideas, and to my wife Diane, who has kept a discerning eye on my activities and the progress of the series.

Alan HaLe 


\section{Contents}

Editor's Introduction

Preface

xiii

Chapter 1 Information and business 1

1.1 Introduction 1

1.2 A business analysed 1

1.3 A survey of business information 3

1.4 Conclusions $\quad 5$

Review questions 6

$\begin{array}{lll}\text { Chapter } 2 & \text { Formulating the problem } & 7\end{array}$

2.1 Introduction $\quad 7$

$\begin{array}{ll}2.2 \text { Why a problem? } & 7\end{array}$

2.3 Defining the problem $\quad 8$

$\begin{array}{ll}2.4 \text { Resolving difficulties } & 10\end{array}$

2.5 Defining the solution 11

$\begin{array}{ll}2.6 \text { Data } & 13\end{array}$

$\begin{array}{ll}2.7 \text { Summary } & 15\end{array}$

Review questions 16

$\begin{array}{lll}\text { Chapter } 3 \text { Information handling without a computer } & 17\end{array}$

$\begin{array}{lll}3.1 \text { Introduction } & 17\end{array}$

3.2 Characteristics of information handling problems $\quad 17$

$\begin{array}{ll}3.3 \text { Computational aids } & 18\end{array}$

3.4 Dealing with the written word 19

3.5 Limitations imposed by the equipment 21

$\begin{array}{ll}3.6 \text { Summary } & 22\end{array}$

Review questions $\quad 22$

Chapter 4 The computer as a tool in problem-solving 24

4.1 Introduction 24 
4.2 Facilities $\quad 24$

$\begin{array}{ll}4.3 \text { Hardware } & 26\end{array}$

$\begin{array}{lll}4.4 & \text { Software } & 33\end{array}$

4.5 Information in the computer $\quad 34$

$\begin{array}{ll}\text { 4.6 Data preparation } & 35\end{array}$

$\begin{array}{lll}4.7 & \text { An application } & 35\end{array}$

$\begin{array}{ll}4.8 \text { Conclusion } & 38\end{array}$

$\begin{array}{ll}\text { Review questions } & 38\end{array}$

Chapter 5 Programming language and software 40

$\begin{array}{lll}5.1 & \text { Introduction } & 40\end{array}$

5.2 Purpose and types of language $\quad 40$

5.3 Structure of programming languages $\quad 42$

5.4 Fortran 44

5.5 Cobol $\quad 47$

5.6 Algol 49

5.7 Which language? $\quad 52$

$\begin{array}{ll}5.8 \text { Software } & 54\end{array}$

5.9 Summary $\quad 55$

Review questions $\quad 55$

Chapter 6 Planning for a computer application 56

6.1 Environment 56

6.2 The feasibility study $\quad 56$

6.3 Defining terms of reference $\quad 58$

6.4 Establishing systems objectives $\quad 59$

6.5 Advisory role of the systems analyst $\quad 59$

6.6 Factors involved in a feasibility study $\quad 60$

$\begin{array}{ll}6.7 \text { Assessing costs and benefits } & 61\end{array}$

$\begin{array}{ll}6.8 \text { Summary } & 62\end{array}$

Review questions $\quad 63$

Chapter 7 Data capture 64

$\begin{array}{lll}7.1 \text { Introduction } & 64\end{array}$

$\begin{array}{lll}7.2 & \text { Data entry - a future perspective } & 64\end{array}$

$\begin{array}{lll}7.3 \text { Order entry } & 65\end{array}$

$\begin{array}{ll}7.4 & \text { Data collection in the factory } 68\end{array}$

7.5 Developing methods of data collection 68

$\begin{array}{ll}7.6 \text { Summary } & 69\end{array}$

$\begin{array}{ll}\text { Review questions } & 70\end{array}$

$\begin{array}{lll}\text { Chapter } 8 & \text { Data validation } & 71\end{array}$

$\begin{array}{lll}8.1 \text { Introduction } & 71\end{array}$

8.2 The blind leading the blind 71

$\begin{array}{ll}8.3 \text { Sources of error in input data } & 71\end{array}$ 
Contents $\quad \mathrm{xi}$

8.4 Prevention of errors in the recording of data 72

8.5 The presentation of data 73

8.6 Data preparation 73

8.7 Validating the data $\quad 74$

8.8 Reducing the error content 77

$\begin{array}{ll}\text { 8.9 Summary } & 77\end{array}$

Review questions $\quad 78$

Chapter 9 The storage and retrieval of information 79

9.1 Introduction 79

9.2 Equipment for information storage and retrieval 79

9.3 Choice of equipment 84

9.4 Summary $\quad 85$

Review questions $\quad 86$

$\begin{array}{lll}\text { Chapter } 10 & \text { Preparing for systems design } & 87\end{array}$

$\begin{array}{lll}10.1 & \text { Meeting people } & 87\end{array}$

10.2 Scope of systems investigation 88

10.3 Execution of the systems investigation 92

10.4 Summary 93

Review questions $\quad 94$

Chapter 11 Emergence of a system 95

11.1 Systems analysis $\quad 95$

11.2 Establishing a systems team 96

11.3 Definition of output requirements 96

11.4 Assessment of available inputs 98

11.5 Definition of processes $\quad 98$

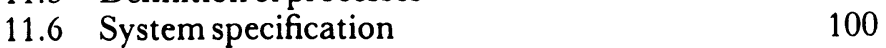

Review questions 101

Chapter 12 Development of computer processes 102

$\begin{array}{lll}12.1 & \text { Introduction } & 102\end{array}$

12.2 Input to output 102

12.3 Aids in design 104

12.4 Testing and implementation 113

12.5 Nature of test data 119

12.6 Documentation 120

12.7 Methodologies for large systems $\quad 121$

$\begin{array}{ll}\text { Review questions } & 122\end{array}$

Chapter 13 Organisation of a computer department 124

13.1 Introduction 124

13.2 Overall responsibility for computing 124

13.3 Computer steering committee 125 
xii

13.4 Organisation within the department

13.5 Other ways of obtaining a computer service 129

13.6 Summary

131

Review questions

Chapter 14 Implementing, evaluating and reviewing the system

14.1 Introduction

14.2 Role of the project leader

14.3 Priorities of the project leader

14.4 Progress of systems implementation

14.5 Evaluating and reviewing the system

14.6 Computer systems audit

14.7 Conclusions

Review questions

Chapter 15 Standards

15.1 Introduction 139

15.2 Why standards? 139

15.3 What are standards? 140

15.4 Definition of standards 141

15.5 Standard standards? $\quad 142$

15.6 Summary 144

Review questions 144

Chapter 16 Systems now . . and then? 146

16.1 Introduction 146

16.2 Integrated file structures and databases 146

16.3 Software considerations - software packages 147

16.4 State of the art 148

16.5 Developing technology - the micro-computer

16.6 Future developments 152

16.7 Conclusions 153

Review questions 153

Chapter 17 The moral question 154

17.1 Introduction 154

17.2 Data privacy 154

17.3 Computers and the quality of life 156

17.4 The question of responsibility 158

17.5 Conclusions 160

Review questions $\quad 160$

Further Reading 161

Index 163 


\section{Preface}

The mechanisation of processes throughout industry has provided the most significant period of change ever seen in our industrial life. Nowhere has this been more significant than in the handling of information. The everincreasing complexity of business life has given rise to the need for more and more information for the control and operation of the business, and this demand for information has stimulated the development of highly sophisticated computer-based systems for its provision.

This book is about computers, but it is also about information, and the role which computers play in solving information-processing problems. It will not tell you how computers work, or how to write programs in a particular programming language. It does however concern itself with ways of solving problems, the use made of computers in that context, and the role that they play in business activities. The student who is interested in learning how the computer works, or how to program it to solve problems, will find many excellent books which have been published with this aim in mind.

You will learn to recognise the type of problem which can best be handled on a computer and how to formulate that problem in a meaningful way for its solution by computer. In implementing an appropriate solution on the computer you will usually be supported by systems analysis and programming staff, and the book outlines the way this group of staff set about their task. The intention is that you will be able to play an effective role working alongside them in systems development. To do this you do need to understand what you can expect from the computer, and a conceptual picture is given as to how the machine carries out problem-solving and information-management.

The book is intended for the student of business; line managers are students of business, and so are accountants, personnel officers, production supervisors and shop stewards - and a host of other employees of the modern business organisation. All are having to learn new ideas about the intractable problem of keeping information moving, in order to keep the business moving. Equally, the book provides for the needs of students studying computing as an option in Business and Management courses. It attempts to impart an appropriate level of knowledge about the subject for such students to be able to enter into constructive discussion with computer systems specialists; it attempts also to provide an understanding of computer techniques for the student to make an effective contribution to the design of information-processing systems. 
The review questions have been designed with particular regard for the approach called for in the new BEC courses, where the student's knowledge of a subject must be combined with reasoning skills and the ability to communicate effectively. The discussion points also provide a good basis for the level of seminar discussion expected in a B.A. Business Studies course.

It has been our intention to break down many of the barriers which so often exist between computer specialists and their long-suffering customers, by enabling the latter to come to terms with a lot of the jargon and the methods used by the computer scientist, and allow systems to be developed in a spirit of cooperation and understanding between the two sides.

In attempting this difficult task, we have been indebted to the many people whose ideas and enthusiasm have encouraged us in our efforts - and especially to our respective wives, Sarah and Maralynn, for their patience and understanding.

Peter M. Haine

ERnEST E. J. HaIdon 